\title{
AIR CARGO AND AIRPORT COMPETITIVENESS
}

Thomas Van Asch (corresponding author)

Department of Transport and Regional Economics, University of Antwerp, Belgium

Wouter Dewulf

Department of Transport and Regional Economics, University of Antwerp, Belgium

Franziska Kupfer

Department of Transport and Regional Economics, University of Antwerp, Belgium

Hilde Meersman

Department of Transport and Regional Economics, University of Antwerp, Belgium

Evy Onghena

Department of Transport and Regional Economics, University of Antwerp, Belgium

Eddy Van de Voorde

Department of Transport and Regional Economics, University of Antwerp, Belgium

\begin{abstract}
Historically, airlines and airports considered air cargo as a by-product. However, by looking for additional sources of revenue, airlines and airports became aware of the potential of air cargo. In this study, the competitiveness of European airports with respect to air cargo will be discussed. The relevant characteristics determining the competitiveness of an airport with respect to air cargo are identified by an extensive literature review and by interviews with industry-specialists. These characteristics can be divided into four different components: territory, air cargo marketplace, airport operations and product differentiation. Each component consists of several factors affecting airport competitiveness for cargo. This study can be used by airports to help assessing and enhancing its air cargo strategy, whereas (potential) shareholders are given an additional instrument to check whether an investment in an airport makes would be viable or not.
\end{abstract}

\section{KEYWORDS}

air cargo; airport strategy; airport competitiveness 


\section{INTRODUCTION}

For a long time, air cargo was considered a by-product of passenger services in air transport; airlines and airports paid little attention to the air cargo segment. However, things changed considerably during the last decade and most airlines and airports have created their own cargo strategy as both were looking for additional sources of revenue. Declining yields in the passenger segment, as well as improved cargo payload capacity of new aircraft types have led air cargo to become a logical way for traditional airlines to expand their portfolios. For many airlines, cargo nowadays makes an important contribution to the profitability of the longdistance passenger routes offered (Amaruchkul and Lorchirachoonkul, 2011; Zhang, 2003; Zhang and Zhang, 2002). While air cargo accounts for only $1 \%$ to $2 \%$ of total freight by weight transported globally, it represents $35 \%$ of trade expressed in value (ATAG, 2018). Because of its speed and reliability, typical air cargo goods include pharmaceutical products, electronics, perishable goods (e.g. flowers and fruit), urgent shipments, valuable goods and e-commerce (Alkaabi and Debbage, 2011). Air cargo transport is predicted to grow 3.51\% until 2022 (Kupfer et al., 2017), whereas Boeing (2018 and 2016) forecasted a yearly growth rate of between $2.3 \%$ to $4.9 \%$ until 2035 . These growth numbers are primarily driven by the growing Asian market and the flourishing e-commerce segment.

Macário (2008) defined the role of airports as: "(...) providers of a high technological demanding infrastructure, of national strategic interest, for very sophisticated operations where safety played both a very distinguished and distinct role". Historically, airports were state-owned entities, especially because of the large investment costs. Adler and Liebert (2014) confirmed the widely adopted idea of airports facing significant economies of scale. Airport competition has been considered as non-existing for a long time and airports were viewed as natural monopolies. However, since two decades, the situation has changed and the idea of airports being monopolies lost its support. Adler and Berechman (2001) mentioned that "airports can be regarded as organizations that make decisions about how to use their inputs (e.g. number of runways) to produce specific outputs (e.g. service satisfaction)". This does not mean that all airports take the same strategic decisions. On the contrary, depending on the airport characteristics, different strategies can be observed. Therefore, an analysis of the cargo characteristics of an airport and its impact on airport strategy can give important insights for future development and growth of the airport, especially because of the increasing focus on carrying goods by air in today's globalized economy. 
Although interest in air cargo has increased, limited academic literature is available on the competitiveness of airports with respect to cargo. Studies about the role of the freight forwarder in the business (e.g. Adenigbo, 2016) were found in the literature as was research on the role of integrators at an airport (e.g. Malighetti et al., 2016). The impact of full freighters at an airport (e.g. Budd and Ison, 2017) and the issue of night curfews (e.g. Oosterlynck and Swyngedouw, 2010) have also already been discussed in the literature. However, no single study is known which focuses on airport competitiveness with respect to cargo from the strategic perspective of the airport. This study aims to fill this research gap. More specifically, this study will focus on the different factors that contribute to the competitiveness of an airport with respect to air cargo. To capture the myriad of factors that play a role, an extensive literature review was performed and was supported by additional semi-structured interviews with industry representatives ${ }^{1}$. With this, we attempt to identify which factors determine the competitiveness of an airport with respect to air cargo. The remainder of this study is structured as follows: the next section will give a general introduction into airport competition. Section three will present the relevant factors for airport competitiveness in the cargo segment and the last section will discuss the results and conclude.

\section{AIRPORT COMPETITION}

In the mid-eighties, the European aviation market was described as "a world of non-competing airlines [that] has been mirrored by a world of non-competing airports" (Barrett, 2000). Since then, things have changed dramatically. Airline deregulation initiated competition between airlines and airline alliances, and subsequently led to (some) competition between (hub) airports (Starkie, 2002). Moreover, the privatization and commercialization of airports made airport competition an increasingly important issue. Forsyth (2006) indicated that airports under public ownership were perceived as natural monopolies that were not competing with each other. The commercialization and privatization trend that took place in the aviation industry could not completely neutralize this monopoly power and the author sees this as a good reason to justify price regulation on airports. Graham (2014) confirmed this view on

\footnotetext{
1 Semi-structured interviews were conducted with several different airports within Europe. Furthermore, representatives from integrators, freight forwarders, NPO's, last-mile delivery companies, airlines and customs were also interviewed about their opinion on the output of the literature review. Basically, most industry-specialists agreed with the output and only minor changes were made on the airport competition components. The identity of the interviewees is confidential and known by the supervisors.
} 
airport competition but added that both the formation of global alliances and the emergence of the low-cost market segment further opened up competition between airports. Copenhagen Economics (2012) found some additional reasons for the changed business environment in which airports are competing nowadays. Next to the development of low-cost airlines, commercial and technological changes, for example, growing incomes in combination with lower airfares meant that passengers could more easily spend money at airports and make more trips by air. Also, the fact that more people have internet access means that better and more accurate information is available to passengers concerning different airline and airport options (Copenhagen Economics, 2012; Forsyth, 2006; Graham, 2014).

Airports can compete with each other in different ways, and therefore, airport competition can have several forms (Forsyth, 2006). First, airports are in competition with each other for a particular type of traffic, e.g. low-cost traffic or cargo. Next, airports are in competition with each other to attract hub carriers and - closely related to this - also to attract home carriers. The location of the airport is highly influential in the competition between airports, though not necessarily only in the catchment area. Also, competition for concession revenue is seen as important by Forsyth (2006). Graham (2014) revealed that if airports are located in the same catchment area, there is often one dominant player and one secondary airport. Whereas the dominant player can be seen as a major airport, the latter could be an overspill airport, focusing on a particular traffic segment (e.g. short-haul business flights, low-cost flights or cargo). In assessing the competitiveness of an airport, the substitution possibilities also have to be considered. The threat of a new airport is often perceived to be quite low; however, the competition from other transport modes is apparent. High-speed railways are not only a viable alternative for short-haul, but possibly also for medium-haul passenger flights. Better road and railway infrastructure, in general, makes it more convenient to reach major airports. This lowers, for example, the need for feeder services from regional airports. Substitution is clearly highly dependent on the type of traffic one takes into account. However, airfreight, using air transport for its speedy and reliable service, often has a very limited number of alternatives available (Graham, 2014).

Competition between airports is further intensified due to three typical characteristics of the airport industry. Airports are largely fixed costs businesses which are active in a two-sided market and are geographically fixed, a fact confirmed by Starkie (2002). Another important competitive pressure for airports is the threat of airlines switching between airports, as was 
found by Copenhagen Economics (2012). However, a study by IATA refuted that airlines can easily switch between airports (IATA, 2013).

The previous paragraphs show that the argument of airports being monopolies has lost most of its support; however, airports still have some locational monopolistic power. Airports are located in a specific area and it is often difficult to add new capacity in that area. Forsyth (2006) verified a (limited) locational natural monopoly for two or more airports in the same city. Even in an oligopolistic market with limited capacity, competition is imperfect. Furthermore, airports realize scale economies and new airports face entry barriers such as the unavailability of land and opposition from politicians and people for environmental reasons. Another barrier for competition is the excess demand and subsequent congestion of some major airports. On the one hand, major airports are often negatively impacted by congestion. However, it is unlikely that a new airport can take advantage of this situation because passengers and airlines do not see the new airport as a viable substitute but rather as an inferior product (for example, the lack of connections). However, those airports are often preferred by freight carriers because some of these carriers traditionally prefer to fly into secondary airports as do low-cost carriers. The impact of the government (be it by regulation or subsidies) is also hampering smooth competition between airports.

Airport competitiveness with respect to cargo is a very specific research area and limited academic research has been undertaken in this domain. The next section will introduce the relevant factors that determine the competitiveness of an airport within the cargo segment. Section three will start with a global overview of the factors taken into account in this study, with a further elaboration of each.

\section{FACTORS DETERMINING THE AIRPORT COMPETITIVENESS FOR AIR FREIGHT}

An extensive literature review was performed to identify the various factors determining the competitiveness of an airport with respect to air cargo. The identified factors will be explained in detail in the following paragraphs. It is important to keep in mind that linkages between the defined components exist and that all components have to be considered holistically if the overall competitiveness of an airport is to be assessed. Moreover, shareholders' objectives are essential. Depending on the shareholders' objectives, airport management will take different 
strategic actions and make different decisions. Figure 1 summarizes the identified factors within the four major components noted previously.

Figure 1. Components of Airport Competition

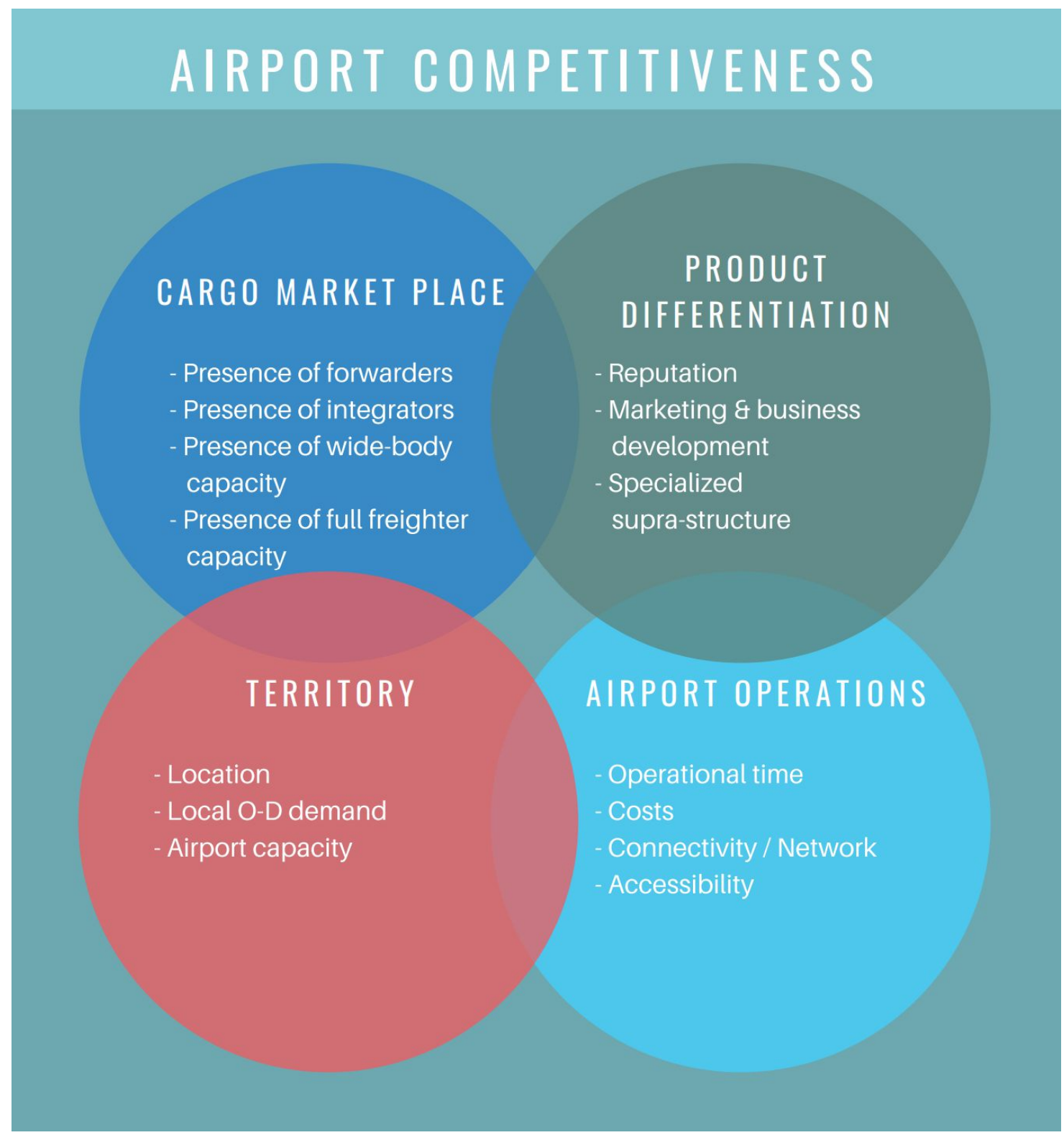

Source: own composition

Figure 1 is based upon the overview of the academic research summarised in Table 1. It has to be kept in mind, however, that not all of the factors in Figure 1 can be influenced by airport management (e.g. territory block) and are thus rather exogenous. However, others are in direct or indirect control of airport managers (e.g. costs, reputation, presence of freight forwarders) and could be used to shape and or adjust the airport strategy for air cargo. 
Table 1. Literature Overview

\begin{tabular}{|c|c|}
\hline \multicolumn{2}{|r|}{ TERRITORY } \\
\hline Location & $\begin{array}{l}\text { Fuerst and Gross, 2018; Mayer, 2016; Wong et al., 2016; Bowen, 2012; Boquet, 2009; Gardiner and Ison, 2008; } \\
\text { Gardiner et al., 2005a; Gardiner et al., 2005b; Zhang, 2003; Air Transport World, 2002; Noviello et al., 1996; Dennis, } \\
\text { 1994; Schwieterman, 1994; O'Kelly, 1986; Harris, 1954 }\end{array}$ \\
\hline Local O-D demand & $\begin{array}{l}\text { Boonekamp and Burghouwt, 2017; Kupfer et al., 2016; Bowen, 2012; Alkaabi and Debbage, 2011; Gardiner and Ison, } \\
\text { 2008; Cosmas and Martini, 2007; Zhang, 2003; Hall, 2002; Zhang and Zhang, } 2002\end{array}$ \\
\hline Capacity & Adenigbo, 2016; Magalhães et al., 2015; Basso and Zhang, 2010; Madas ans Zografos, 2008; Neiberger, 2008 \\
\hline \multicolumn{2}{|r|}{ CARGO MARKET PLACE } \\
\hline $\begin{array}{l}\text { Presence of freight } \\
\text { forwarders }\end{array}$ & $\begin{array}{l}\text { Boonekamp and Burghouwt, 2017; Kupfer et al., 2016; Burghouwt et al., 2014; Chu, 2014; Li et al., 2012; Rodrigue, } \\
\text { 2012; Tretheway and Andriulaitis, 2010; Yuan et al., 2010; Air Cargo World, 2001 }\end{array}$ \\
\hline $\begin{array}{l}\text { Presence of } \\
\text { integrators }\end{array}$ & $\begin{array}{l}\text { Malighetti et al., 2016; Struyf, 2016; Onghena, 2013; Bowen, 2012; Alkaabi and Debbage, 2011; Lafaye, 2007; Gardiner, } \\
\text { 2006; Bowen, 2004; Zhang and Zhang, } 2002\end{array}$ \\
\hline $\begin{array}{l}\text { Presence of wide- } \\
\text { body capacity }\end{array}$ & $\begin{array}{l}\text { Lange, 2019; Boeing, 2018; Boonekamp and Burghouwt, 2017; Budd and Ison, 2017; de Wit et al., 2017; Kupfer et al., } \\
\text { 2017; Kupfer et al., 2016; Mayer, 2016; Merkert and Ploix, 2014; Hsu et al., 2009; Bowen, } 2004\end{array}$ \\
\hline $\begin{array}{l}\text { Presence of full } \\
\text { freighter capacity }\end{array}$ & $\begin{array}{l}\text { Boonekamp and Burghouwt, 2017; Budd and Ison, 2017; Kupfer et al., 2017; Airbus, 2015; Gardiner et al., 2005a; } \\
\text { Bowen, 2004; Zhang and Zhang, 2002 }\end{array}$ \\
\hline \multicolumn{2}{|r|}{ AIRPORT OPERATIONS } \\
\hline Operational time & $\begin{array}{l}\text { Kupfer et al., 2016; Chao and Yu, 2013; Oosterlynck and Swyngedouw, 2010; Tretheway and Andriulaitis, 2010; } \\
\text { Gardiner et al., 2005b; Delve, 2001; Shaw, } 1993\end{array}$ \\
\hline Costs & $\begin{array}{l}\text { Yuen et al., 2017; Adenigbo, 2016; Fichert and Klophaus, 2011; Kupfer et al., 2011a; Tretheway and Andriulaitis, 2010; } \\
\text { Gardiner et al., 2005b; Zhang, 2003; Adler and Berechman, 2001; Barrett, 2000 }\end{array}$ \\
\hline $\begin{array}{l}\text { Connectivity - } \\
\text { network }\end{array}$ & $\begin{array}{l}\text { Boonekamp and Burghouwt, 2017; Ben-Akiva et al., 2013; Chao and Yu, 2013; Chung and Han, 2013; Kim and Park, } \\
\text { 2012; Kupfer et al., 2011b; Heinitz and Meincke, 2009; Malighetti et al., 2009; OSC et al., 2009; Ohashi et al., } 2005\end{array}$ \\
\hline Accessibility & $\begin{array}{l}\text { Boonekamp and Burghouwt, 2017; Struyf et al., 2016; Heinitz et al., 2013; Bowen, 2012; Schramm, 2012; Kupfer et } \\
\text { al., 2011a; Tretheway and Andriulaitis, 2010; Gardiner et al., 2005b; Hall, 2001 }\end{array}$ \\
\hline \multicolumn{2}{|r|}{ PRODUCT DIFFERENTIATION } \\
\hline Reputation & $\begin{array}{l}\text { Kupfer et al., 2016; Hwang and Shiao, 2011; Gardiner and Ison, 2008; Gardiner et al., 2005b; Ohashi et al., 2005; } \\
\text { Zhang, 2003; Adler and Berechman, 2001; Murphy et al., } 1989\end{array}$ \\
\hline $\begin{array}{l}\text { Marketing \& business } \\
\text { development }\end{array}$ & $\begin{array}{l}\text { Fichert and Klophaus, 2011; Yuan et al., 2010; Gardiner and Ison, 2008; Macário, 2008; Gardiner et al., 2005a; Lee } \\
\text { and Yang, } 2003\end{array}$ \\
\hline $\begin{array}{l}\text { Specialized supra- } \\
\text { structure }\end{array}$ & $\begin{array}{l}\text { Elliott and Bonsignori, 2019; Graham, 2014; Tretheway and Andriulaitis, 2010; Gardiner et al., 2005b; Kasarda and } \\
\text { Green, 2005; Page, 2003; Zhang, 2003; Zhang and Zhang, 2002; Kingsley-Jones, } 2000\end{array}$ \\
\hline
\end{tabular}

Source: own composition 


\subsection{Component 1: Territory}

The Territory component contains factors related to the geographical location of the airport. Different studies have mentioned the importance of location and see it as a crucial factor in the assessment of the competitiveness of an airport. However, other factors that are closely linked to location are also relevant; origin-destination (O-D) demand in the catchment area of the airport is a good example. The third major factor taken into consideration is airport capacity. Especially in Europe, capacity seems to be a very relevant issue, as is evidenced by the number of airports operating at almost full capacity such as London Heathrow (LHR) and Amsterdam Airport Schiphol (AMS).

\section{Location}

The two main advantages of air cargo transport compared to other transport modes are speed and reliability. Therefore, air cargo is usually used for time-sensitive goods (e.g. e-commerce and pharmaceuticals), valuable items and perishables. Zhang (2003) indicated that if "all other factors equal, the ideal hub location is one that minimizes the total flight kilometres within a network and allows services with larger aircraft". This illustrates the relevance of a central location of an airport for hub activities: minimizing flying time and costs (Air Transport World, 2002; Dennis, 1994; Schwieterman, 1994). By doing a k-means cluster analysis, Wong et al. (2016) confirmed a study by Zhang (2003) that Hong Kong is the most competitive airport for cargo in the Asia-Pacific region because of its central location. However, as Dennis (1994) clearly mentioned in his study of passenger airline hub operations in Europe, the ideal location of a hub depends on the markets one wants to serve. The same is valid for cargo operations. Studies by - amongst others - Harris (1954), Noviello et al. (1996), and O'Kelly (1986) looked for the most appropriate national cargo hub in the US: All studies revealed that the area around Southern Ohio was the best choice due to its central location. Bowen (2012) mentioned the superior location of Louisville compared to Chicago for the US activities of UPS. Boquet (2009) found that airports with a strategic location - like Anchorage, Doha, Abu Dhabi and Dubai - can focus more easily on transshipment cargo activities. A study by Schwieterman (1994) looked for the most attractive air cargo hub in the Pacific Rim by considering 15 major Asian cargo centres. The preferred hub location was South China, and more specifically, the airports in Hong Kong, Taiwan, Manila, Guangzhou and Shenzhen.

A study about non-aeronautical passenger revenues by Fuerst and Gross (2018) used airport location as a proxy for economic development in the surrounding area of the airport. For the cargo segment, Gardiner et al. (2005a, 2005b) and Gardiner and Ison (2008) conducted several interviews with non-integrated cargo operators to shed light on their airport decision process. An important conclusion of these studies is that in the first stage of the airport choice 
process, carriers look for an appropriate location or region. Once the location has been chosen, the airport with the highest financial return potential will be chosen. That return depends not only on the costs of operating at the airport but also on the local air cargo demand. Gardiner and Ison (2008) and Mayer (2016) also noted a correlation between the focus of an airport on cargo and - amongst others - its geographical location, manufacturing base and the airlines operating at the airport.

It may be clear that airports with a favourable location have an absolute competitive advantage over other airports. However, defining 'a favourable location' is a case-by-case issue that depends heavily on the type of activities one wants to develop at the airport.

\section{Origin - Destination Demand}

Especially for origin-destination (O-D) airports (e.g. Milan Malpensa Airport), local O-D demand is a top-level factor to consider. These airports do not act as hubs and are, therefore, almost fully dependent on the local market. Gardiner and Ison (2008) found that it is important for these airports to be located close to an economic cluster because it is an indication of higher demand. A study by Zhang and Zhang (2002) stated that freighter operations will be located where sufficient local demand is generated. Zhang (2003) divided the markets relevant to Hong Kong Airport into three different parts: local traffic, gateway traffic, and hub traffic. Generally, an airport faces very little competition for local traffic, whereas the competition for gateway cargo is rather fierce between airports in the same catchment area (Boonekamp and Burghouwt, 2017; Kupfer et al., 2016; Zhang, 2003). Regarding hub traffic, airports face competition from other hub airports which are not necessarily in close proximity of the airport. LHR and Dubai International Airport are for instance close competitors of each other on most Europe-Asia routes.

Besides the different types of airports, there are also different types of carriers serving the cargo market. Whereas combination carriers prefer to co-locate cargo and passenger services at their hub airports (Hall, 2002), all-cargo carriers are more likely to choose O-D airports (comparable to low-cost carriers in the passenger segment). The latter are $100 \%$ focused on transporting cargo, whereas for most combination carriers, cargo is not the main focus of their business and their airport choice is mainly dependent on their passenger routes. The airport choice for passenger activities will not be elaborated further upon in this paper. For readers that are interested in the airport choice of passenger airlines, a wide range of papers can be found in the literature, e.g. Shaw (1993), Rodríguez-Déniz et al. (2013), etc.

The combination of a good location and local O-D demand is probably of greatest importance for the integrators (DHL, FedEx and UPS), as studies by Alkaabi and Debbage (2011), Bowen 
(2012), Cosmas and Martini (2007) and Hall (2002) show. These companies guarantee fast delivery times for which a close location to the market is key; in addition, sufficient local demand gives security to their business.

\section{Airport Capacity}

Assessing airport capacity is not just limited to slot allocations and or/restrictions. However, almost all academic research dealing with capacity issues at airports concerns 'slots' (e.g. Adenigbo, 2016; Madas and Zografos, 2008). Slot allocation is a major issue at the vast majority of major airports. Most of these airports try to allocate slots as much as possible to passenger flights because they generate higher income (Basso and Zhang, 2010). Such an allocation policy, together with the unpredictability of air cargo, and therefore, their need for flexible slots, makes it difficult for cargo carriers and/or cargo flights to set up activities at these airports as has been seen at AMS. In 2019, the Dutch government decided against an increase in the number of flight movements at AMS (currently set at 500,000). Because intercontinental passenger flights are financially more beneficial for the airport, as many slots as possible are allocated to such flights. As a result, full freighter airlines experience particular difficulties operating at AMS, and the first signs of negative growth in the cargo segment at the airport can already be observed ${ }^{2}$.

However, more factors regarding capacity need to be considered, especially if air cargo is taken into account. A study by Magalhães et al. (2015) touched very briefly upon expansion on the landside for future developments. The potential for expansion at an airport can be high relevant for the air cargo segment, especially because the industry is consistently growing every year. In particular, cross-border e-commerce logistics generates high growth figures and companies active in the e-commerce segment are continuously evaluating possibilities for further expansion to optimize their business. $\mathrm{DHL}$, for example, recently opened a new sorting hub at BRU as a response to the booming cross-border e-commerce market (Air Cargo World, 2018). Such investments are beneficial for the whole airport community because of - amongst others - the additional added value and employment that is created (Neiberger, 2008).

\subsection{Component 2: Cargo Market Place}

The second component - the cargo market place - includes factors related to the different actors in the air cargo transport/delivery chain. As freight forwarders still control a large share of the air cargo customer front end, the presence of these companies at an airport is highly appreciated by other actors in the transport chain. Furthermore, the enormous growth of

\footnotetext{
${ }^{2}$ Kalitta Air, for example, has lost slots at AMS in 2019, forcing it to redirect its flights to other airports, including OST and BRU in Belgium (Nieuwsblad Transport, 2019).
} 
Asian and Middle Eastern carriers in the last two decades occurred in tandem with a strong increase in the number of wide-body aircraft. These aircraft are exceptionally well designed to carry cargo in the belly space. A good mix of wide-bodies and full freighter aircraft at an airport is, therefore, a precondition to establish a competitive position in the market.

\section{Freight Forwarders' Presence}

Contrary to the maritime industry, freight forwarders (logistics service companies arranging the transport of goods from origin to final destination) and integrators such as DHL and FedEx still control the majority of the air cargo transport chain (Air Cargo World, 2001; Tretheway and Andriulaitis, 2010). Kupfer et al. (2016) stressed the important role of freight forwarders in the air cargo market. Having a wide range of freight forwarding companies present at the airport is said to be beneficial for the airport to attract cargo business (Kupfer et al., 2016; Tretheway and Andriulaitis, 2010). Airlines that fly to long-haul destinations (and thus have a significant amount of belly space available) from a particular airport, benefit from the presence of a wide range of freight forwarders at that airport because these carriers try to optimize their bellyhold capacity via the spot market. The freight forwarding business mainly revolves around the consolidation of smaller shipments from different shippers into larger consignments. (Boonekamp and Burghouwt, 2017; Burghouwt et al., 2014; Chu, 2014; Li et al., 2012) The non-integrated airlines also rely heavily on the freight forwarding business. These airlines see the presence of a wide range of freight forwarders at an airport as an indication of enough local volume (i.e. demand) for the development of a sustainable cargo service. Freight forwarders on their part cluster together in the proximity of an airport in order to optimise their operations because of the time-sensitivity of air cargo (Rodrigue, 2012) and do not want to fragment their flows from different airports within the same catchment area (Yuan et al., 2010). Moreover, these companies prefer airports which can offer a broad range of long-haul destinations to ensure that their cargo can reach a wide range of destinations in a fast and efficient way.

\section{Integrators' Presence}

At times, the presence of an integrator can also be beneficial in attracting airlines (Gardiner, 2006) and, therefore, enhance the competitiveness of an airport. Onghena (2013) looked into the business of integrators at the largest airports for cargo in Europe. The same is done in Table 2, although updated with more recent numbers. 
Table 2. Top-10 European airports for cargo throughput (in tonnes)

\begin{tabular}{|c|c|c|c|c|c|}
\hline $\begin{array}{l}\text { European } \\
\text { rank }\end{array}$ & $\begin{array}{l}\text { Worldwide } \\
\text { rank }\end{array}$ & Airport & $\begin{array}{c}\text { Tonnage } \\
2017\end{array}$ & $\begin{array}{l}\text { \% change } \\
2016 \text { / } 2017\end{array}$ & $\begin{array}{c}\text { Main cargo carriers at the } \\
\text { airport }\end{array}$ \\
\hline 1 & 10 & CDG & 2.195 .229 & 2.8 & $\begin{array}{l}\text { FedEx (main European hub) } \\
\text { Air France - KLM (main hub) }\end{array}$ \\
\hline 2 & 11 & FRA & 2.194 .058 & 3.8 & $\begin{array}{l}\text { DHL } \\
\text { Lufthansa (main hub) }\end{array}$ \\
\hline 3 & 17 & LHR & 1.794 .276 & 9.4 & IAG Cargo (main hub) \\
\hline 4 & 18 & AMS & 1.778 .382 & 4.9 & $\begin{array}{l}\text { Air France - KLM (main hub) } \\
\text { AirBridgeCargo, Cathay Pacific }\end{array}$ \\
\hline 5 & 25 & LEJ & 1.131 .382 & 8.0 & $\begin{array}{l}\text { DHL (main hub) } \\
\text { Aerologic }\end{array}$ \\
\hline 6 & 26 & IST & 1.095 .518 & 16.2 & $\begin{array}{l}\text { Turkish Airlines (main hub) } \\
\text { MNG Airlines }\end{array}$ \\
\hline 7 & 32 & CGN & 897.132 & 12.0 & $\begin{array}{l}\text { UPS (main European hub) } \\
\text { FedEx (hub) } \\
\text { DHL, Lufthansa }\end{array}$ \\
\hline 8 & 34 & LUX & 822.330 & 6.7 & $\begin{array}{l}\text { Cargolux (main hub) } \\
\text { Panalpina }\end{array}$ \\
\hline 9 & 39 & LGG & 716.894 & 8.5 & $\begin{array}{l}\text { FedEx/TNT (main hub) } \\
\text { Ethiopian Cargo, El Al Cargo, } \\
\text { Kalitta Air, Icelandair }\end{array}$ \\
\hline 10 & 46 & MXP & 589.719 & 7.5 & $\begin{array}{l}\text { Cargolux Italia (main hub) } \\
\text { DHL, FedEx, AirBridgeCargo }\end{array}$ \\
\hline
\end{tabular}

Source: own composition based on WATS (2017) and Onghena (2013)

Table 2 reveals some interesting facts. Almost all of the top cargo airports in Europe have an integrator as one of their major cargo carriers. Integrators - DHL, FedEx and UPS - are fully integrated logistics service providers that operate their own or wet-leased aircraft. These companies - originally focusing on the fast delivery of small shipments - are an important driver of the growing e-commerce market (Bowen, 2004; Malighetti et al., 2016; Zhang and Zhang, 2002).

The idea that cargo attracts cargo is also supported by Struyf (2016). She found that larger airports in terms of cargo have developed economies of scale in the cargo segment, whereas small airports with limited cargo activities face diseconomies of scale. This means that airports with well-established cargo activities are more competitive in attracting new cargo services. Furthermore, cargo is concentrated in a number of areas around the world, as was shown by Alkaabi and Debbage (2011) for the US market and by Bowen (2012) regarding the cargo 
hubs for FedEx and UPS. The presence of an integrator is positive for the cargo development at an airport as the integrator already provides a certain cargo volume (because these companies require large operations for both: market presence on the demand size and economic reasons on the cost side) (Lafaye, 2007).

\section{Presence of Wide-body Capacity}

In today's air cargo market, belly space capacity plays a major role. Approximately $50 \%$ of airfreight is carried via the bellyhold of wide-body aircraft, and this share will probably increase further in the future (Boeing, 2018; Boonekamp and Burghouwt, 2017; Kupfer et al., 2016). Narrow-body aircraft, on the other hand, play a negligible role in the air cargo business due to their limited availability of space for air cargo (Boonekamp and Burghouwt, 2017; Lange, 2019).

Wide-body aircraft are exceptionally well designed to carry cargo in the bellyhold. Since the economic and financial crisis of 2008-2009, a number of legacy carriers - foremost the European carriers - are struggling with their cargo divisions (Budd and Ison, 2017). Many of these airlines shifted their focus from carrying cargo in full freighters to the belly space of their passenger aircraft (Boonekamp and Burghouwt, 2017). Wide-body aircraft have also become increasingly important for the air cargo market in the last couple of years as the new wide-body aircraft built by Boeing and Airbus, e.g. B777 or A350, are better designed to carry a larger amount of cargo in their bellies (Boonekamp and Burghouwt, 2017; Budd and Ison, 2017; de Wit et al., 2017; Mayer, 2016). Contrary to full freighter capacity, bellyhold capacity can be used at marginal cost. The direct operating costs of a wide-body flight can mainly be allocated to the passengers on that particular flight, meaning that the incremental costs of transporting cargo in the belly are limited to cargo-handling, additional fuel consumption and some administrative costs (Budd and Ison, 2017; de Wit et al., 2017; Kupfer et al., 2017; Lange, 2019).

Moreover, an airport with a fair amount of wide-body services can give flexibility on the timing and the network. Passenger aircraft can fly into destinations which would not have been viable for full freighters and can serve some destinations more frequently (Boeing, 2018; Bowen, 2004; Hsu et al., 2009). Moreover, these wide-body aircraft can feed the full freighter operations at a particular airport (Boeing, 2018; Hsu et al., 2009; Merkert and Ploix, 2014). However, some limitations have to be taken into account when transporting cargo in a passenger aircraft such as security regulations, cargo dimensions, etc. (Budd and Ison, 2017; Kupfer et al., 2017). 


\section{Presence of Full Freighter Capacity}

Even though a broad range of wide-body capacity is important, it should also be supported by full freighter activities as freight forwarders and shippers tend to move away to other airports in the event that full freighter activities are absent at an airport (Boonekamp and Burghouwt, 2017). However, all-cargo airlines have difficulties in obtaining slots at major gateways such as LHR (Gardiner et al., 2005a) and more recently also at AMS. A study by Airbus (2015) mentioned the strategic advantages for freight forwarders and shippers of full freighter capacity at an airport: greater control over schedules, volumes and routes; broader network (e.g. airports that are not served by passenger flights); ability to transport hazardous and outsized loads which cannot be flown in the belly of passenger aircraft.

On some air routes, the belly capacity of wide-body aircraft does not match the demand and full freighters could cater for this additional demand (Kupfer et al., 2017). Furthermore, some cargo can or may only be shipped by freighters due to its size or hazardous characteristics (Kupfer et al., 2017). These aircraft are also able to carry larger volumes in one single flight and are, therefore, useful to create a larger throughput at the airport (Bowen, 2004). But contrary to passenger flights, full freighters have to deal with unbalanced cargo flows and, therefore, often operate triangular routes (Budd and Ison, 2017; Kupfer et al., 2017; Zhang and Zhang, 2002). Such routings can be a disadvantage for time-sensitive commodities like perishables, pharmaceuticals or e-commerce; in addition, the price of belly capacity is often much cheaper than full freighter capacity.

Next to the integrators, some other carriers are exclusively flying freighters. Kalitta Air, AirBridgeCargo, Nippon Cargo Airlines and Cargolux are some well-known examples (Bowen, 2004). Contrary to most American and European carriers, the Asia-Pacific and Middle Eastern carriers have often well-developed cargo divisions with their own full freighter subdivisions (Budd and Ison, 2017). Budd and Ison (2017) saw two important reasons for this: the strategic geographical location of these countries and the increasing demand for cargo capacity in the emerging economies.

\subsection{Component 3: Airport Operations}

The third component presented in Figure 1 is called airport operations. As indicated, one of the unique selling positions of air transport is speed and reliability (Dewulf et al., 2014; Lange, 2019). In other words, time-efficient handling of air cargo is essential. Furthermore, the network and connectivity of an airport are vital for shippers and freight forwarders to be able to ship their goods around the world. And since air cargo is by nature multimodal, smooth intermodal operations are fundamental for the cargo market. 


\section{Operational Time}

The operational time (operating hours) of an airport have always been controversial, demonstrated, for example, by the move of DHL from Brussels to Leipzig in 2003 (Oosterlynck and Swyngedouw, 2010; Tretheway and Andriulaitis, 2010). Gardiner et al. (2005b) explained the importance of night-time operations, especially for integrators. However, the authors also found that night-time operations are less essential for non-integrated carriers as these airlines have to make a trade-off between conducting 24/7 operations on the one hand, and operating from a main gateway airport on the other hand, which traditionally has night-time restrictions. Nevertheless, $82 \%$ of the questioned non-integrated carriers operating full freighters valued the possibility to operate at night at an airport as either 'important or extremely important'. Kupfer et al. (2016) confirmed this view and added that especially in the Asian market, nighttime operations are a necessity. According to these authors, the main reason for this is that cargo has to leave the Asian continent by night to arrive in Europe in the morning. However, the study by Kupfer et al. (2016) made a clear distinction between major and regional airports. Night-time operations are very important for airlines serving regional airports, whereas airlines active at major European airports are able to schedule their operations around the night-time restrictions.

Delve (2001) considered airports with 24-hour operations as more suitable to attract dedicated cargo traffic and suggested that airports with 24/7 operations have a competitive advantage over others for this type of services. Shaw (1993) clearly indicated that airports should have unrestricted night-time access to attract cargo as well. After reviewing and summarizing the existing literature, Chao and Yu (2013) used the Delphi method to check the relevance of this factor. Airport operational time continues to be seen as an important factor in the assessment of the competitiveness of an airport with respect to cargo. This research approaches the operational time of an airport by examining the night-time restrictions at airports. It is generally accepted that airports that are fully closed at night are less favoured than airports which allow a limited number of night flights or airports without any restrictions.

\section{Airport Costs}

Another factor that airlines take into account when choosing a particular airport are the airport costs or airport charges. Fichert and Klophaus (2011) introduced the following definition: "Airport charges are levied on the use of airport facilities and services". Airport charges can further be divided into aeronautical charges (charges directly related to the operations of an aircraft and the respective passenger services) and non-aeronautical charges based on commercial activities. 
Adenigbo (2016) found that airport charges - together with airport capacity and customs efficiency - were one of the most significant factors in the choice of cargo agents operating in Abuja Airport; this was supported by Tretheway and Andriulaitis (2010). Barrett (2000) demonstrated that airport charges as such were not seen as determining the airport choice of airlines. A more crucial factor was the total cost of operations, which contains airport charges, but also terminal and ground-handling costs, other operating costs, etc. This view was amongst others - confirmed by Kupfer et al. (2011a). Whilst minimizing the total cost of operations is very important for cargo operators (Gardiner et al., 2005b), Gardiner et al. (2005b) found that lower airport charges are a common reason for the relocation of full freighter flights. Yuen et al. (2017) confirmed this view stating that an increase in the charges at a particular airport will decrease the cargo output at that airport and increase the cargo output at another airport. In his study about the cargo airlines' choice of an airport, Zhang (2003) revealed that airport charges for Hong Kong's cargo carriers represent only $7 \%$ of the airline's total cost, thus illustrating that airport charges are of less importance: However, comparing airport costs is a challenge. This is not only because airports define their 'airport fees' differently, but the costs are also dependent upon other factors such as the type of aircraft, time of the day, the number of passenger and tonnes of cargo carried, etc.

Besides airport charges, other costs are important as well. Adler and Berechman (2001), for example, found that labour costs could also be a factor that has to be taken into account. Kupfer et al. (2011a) mentioned labour costs as well, but also referred to other costs: handling cost, fuel cost, line-haul cost, etc. It must be made clear that the airport costs consist of more than just airport charges. Labour costs - still a major input variable in the aviation industry could be a relevant factor that many actors in the industry consider when choosing their airport.

\section{Airport Connectivity - Network}

Connectivity by air is crucial for regional and economic development, which was confirmed by Boonekamp and Burghouwt (2017). Studies by Kupfer et al. (2011b) and Ben-Akiva et al. (2013) found a positive relationship between freight transport and the economic activity within a region.

Malighetti et al. (2009) examined the connectivity of 467 airports within the European aviation network and classified airports based on connectivity. Eight different clusters were defined, ranging from worldwide major hubs to small airports with only a restricted number of routes. However, no particular attention was paid to the cargo segment. Boonekamp and Burghouwt (2017) concluded that (intercontinental) connectivity is a key element in the airport choice for cargo operations. A study by Chung and Han (2013) indicated that flight frequency and flight 
connectivity were almost always mentioned in research about the airport choice for cargo activities, which once again stressed the relevance of both factors. A study by Chao and Yu (2013) mentioned that a wide network of flights goes hand-in-hand with a high availability of cargo transport. To attract transshipment cargo to an airport, Ohashi et al. (2005) also confirmed the importance of an airport's network. Finally, Wong et al. (2016) saw flight frequency and network development as factors in assessing airport competitiveness in the Asian-Pacific air cargo market. The study put Hong Kong and Shanghai Airport as the most suitable to become air cargo hubs in the Asian market, mainly due to their high flight frequency and good network.

As was stated by Boonekamp and Burghouwt (2017), very little literature is available yet on air freight connectivity models. Boonekamp and Burghouwt (2017) described a NetCargo model to benchmark the connectivity of European airports. Kim and Park (2012) used a network quality model for the analysis of cargo transshipments whilst Heinitz and Meincke (2009) on their part built a multi-level air cargo supply-demand interaction model to forecast air freight commodity flows on a global scale. Finally, it is also worth mentioning WorldNet, a freight model developed for the European Commission (OSC et al., 2009).

\section{Airport Accessibility}

Air transport has inevitably a multimodal character, most often combined with road transport to and from the airport (Hall, 2001; Kupfer et al., 2011a). Good accessibility by road helps guarantee fast delivery, which is vital for air cargo (Gardiner et al., 2005b; Hall, 2001). Smaller airports specializing in freight should pay particular attention to good road accessibility (Kupfer et al., 2011a). Road haulage is even more crucial for integrators, especially for their next-day deliveries (Bowen, 2012).

Furthermore, it is worth mentioning that especially within Europe and the US, a large amount of freight is trucked (Boonekamp and Burghouwt, 2017; Heinitz et al., 2013; Schramm, 2012; Struyf et al., 2016; Tretheway and Andriulaitis, 2010), often under an airway bill number. The reasons are manifold, but the excellent road network within Europe and the low cost of trucking are important drivers of this trend.

Since very few European airports use railways for their cargo activities, no further attention will be given to railway connections and their impact on the air cargo market. 


\subsection{Component 4: Product Differentiation}

Within the product differentiation component, the focus of airport management with respect to air cargo will be clarified. The reputation of an airport is seen as an important variable by airlines and freight forwarders. Marketing and business development indicate to what extent an airport is engaged in the cargo business. Airports that advertise their cargo facilities and have a good reputation will probably welcome (new) cargo activities. Offering specialized supra-structure, e.g. dedicated warehouses and equipment, to customers will contribute in a positive way in the airport's attempt to attract cargo.

\section{Airport Reputation}

Adler and Berechman (2001) found that airport quality levels are important in the airport choice of passenger airlines. A study by Zhang (2003) elaborated on the attention airlines pay to customs efficiency when assessing airport quality, a view confirmed by Ohashi et al. (2005). Ground handling services also contribute to airport quality. Different studies - for example, Gardiner et al. (2005b); Gardiner and Ison (2008); Hwang and Shiao (2011); Kupfer et al. (2016) and Murphy et al. (1989) - revealed the importance of a good reputation with respect to air cargo. Although this factor is rather subjective and perceptual, airlines and freight forwarders consider this as relevant. The study by Kupfer et al. (2016) indicated that a good reputation reduces the uncertainty concerning the quality of collaboration between airline and airport, and is seen as even more important in the long-term than financial incentives offered by the airport or airport marketing. Murphy et al. (1989) clearly stated that the quality of cargo services needs to be checked because goods shipped by air are often of high-value, and damage and loss should be minimized. Gardiner and Ison (2008) found that for all-cargo carriers, reputation and experience in handling freighter flights was one of the most relevant factors in their airport choice process.

\section{Airport Marketing and Business Development}

For Gardiner and Ison (2008), an airport is demonstrating its pro-cargo attitude if it is actively promoting its cargo capabilities. The study confirmed a previous one by Lee and Yang (2003) which indicated that airports could attract freighter operators by "intensive competitive strategies and aggressive marketing strategies". In this sense, a study by Macário (2008) is interesting because she found that marketing plays a key role in helping to keep the satisfaction gap as low as possible, meaning that expected and perceived value are matched as closely as possible. Yuan et al. (2010) ascribed the good performance of Hong Kong Airport and Singapore Airport in the cargo segment in 2006 to the fact that both governments listed the development of the logistics industry as one of their top priorities. 
In addition, the topic of financial incentives is often included in the discussion on airport marketing and business development. These financial incentives are commonly used by airports to attract business as was studied by amongst others, Fichert and Klophaus (2011). The role of such financial incentives for the cargo segment, however, remains inconclusive as no research has been performed on this topic. Furthermore, only a limited number of airports have incentive schemes specifically for air cargo. Overall, the impact of airport marketing as such remains highly questionable as it is very difficult to quantify the exact results of airport marketing schemes (Gardiner et al., 2005a).

\section{Specialized Cargo Supra-Structure}

The last factor that is worth mentioning is the specialized cargo supra-structure, such as specialized handling equipment, storage areas, etc. Gardiner et al. (2005b) used a report by the UK government to highlight the need for good supra-structure for the optimal handling of freighters. Compared to passenger activities, more apron space to load and unload the aircraft is needed. In addition, Graham (2014) highlighted the necessity of specialized loading and transfer equipment to support sustainable cargo activities at an airport. Zhang (2003) found that modern transportation, communication, and logistics systems are essential to become an air cargo hub in China. Kingsley-Jones (2000) and Page (2003) confirmed the importance of sufficient ramps, parking spaces, runways and terminal capacity. Tretheway and Andriulaitis (2010) mentioned the importance of the provision of air cargo facilities for freight forwarders at an airport. The most fundamental aspect, however, is the role of customs. The more efficient customs are, the more efficient the cargo flow will be.

The role of customs can influence airport choice (Zhang and Zhang, 2002), a role which was thoroughly analysed by Elliott and Bonsignori (2019). These authors confirmed that customs restrictions are not only disadvantageous for the air cargo business at the airport but also for the economic development of the wider region. The relevance of customs for air cargo development was also mentioned by Kasarda and Green (2005), although these authors state that there is still some ambiguity in the impact customs have on air cargo operations. Within Europe, the differences between customs reliability are limited, but outside of Europe, some major differences could occur. 


\section{CONCLUSION}

Based on the existing literature, this study presented a structure of factors determining the competitiveness of an airport concerning cargo. The vast majority of research about airport competitiveness is quite general or deals with the passenger segment. However, in the last couple of years, more and more scholars have started to focus on the freight segment as well. As a result, many different factors influencing airport competitiveness could be found in the literature. However, to the best knowledge of the author, there is no study that provides an overall overview of these determining factors. Therefore, this study has addressed this topic. The added value of this study is twofold: first, it analysed airport competitiveness from the perspective of the airport itself, and starting from this perspective, an extensive literature review was carried out. Secondly, a wide range of industry representatives was consulted concerning the preliminary research findings. Based on interviews with different stakeholders, the findings were at first validated, and then adjusted where necessary.

The factors that were identified in the literature were subdivided into four different components: territory, cargo marketplace, airport operations, and product differentiation. Within the territory component, factors related to the location of the airport were included. Not only is the geographical location of the airport relevant, but airport capacity issues are also commonly described as important. The second component, the air cargo market place, assessed the air transport chain and related factors. The most important actors are the freight forwarders, integrators and (cargo) airlines. The way in which operations affect the airport competitiveness for cargo is the subject of the airport operations component. Night-time restrictions are limiting for cargo operations. In addition, airport charges also have to be considered, as these are typically closely monitored by full freighter cargo airlines. The network and connectivity of the airport are another major issue to be assessed in determining airport competitiveness, as smoothly organized intermodality facilitates effective and efficient operations. Finally, the product differentiation component revealed the attitude of the airport towards cargo. Some airports are mainly focused on the passenger segment, whereas others focus on cargo. In between both ends of the spectrum, a wide mix of airport types could be found. Reputation, airport marketing, and specialized supra-structure for air cargo are factors that play a major role within this component.

This study can assist policymakers in drafting their aviation policies. Most European airports are - at least to some extent - publicly owned. Therefore, airports are often used as a tool for regional development. The air cargo segment is still a labour-intensive industry and policymakers may want to boost the cargo market to increase employment in their region. Furthermore, this study suggests which factors public authorities should consider when 
attempting to expand air cargo activities at an airport. As it is rather difficult to significantly impact the surrounding region in the short-term, governments can decide upon expansion plans for airports in the longer term, for example, by allowing the construction of new runways. Trying to attract major companies in the air cargo industry (e.g. major freight forwarders, airlines, ground-handlers, e-commerce distributors) is another way to help expand cargo activities at an airport. The role of the government cannot be underestimated in such negotiations, as a supportive government can convince investment from abroad. However, airport operations and product differentiation blocks are also relevant. Labour costs are probably one of the most important cost drivers in the business, so the lower these costs are, the more competitive an airport would be in the industry. Air connections are another key variable, meaning that bilateral agreements with countries that are important freight destinations (e.g. US postal clearance points, major Asian cities like Hong Kong, Seoul, Japan, etc.) are a key element to consider as well. Finally, a good reputation combined with efficient and effective marketing will help to succeed in increasing the air cargo throughput. All these variables should be taken into account by public authorities while drafting their airport policies to support the air cargo market at their airports.

Policymakers that want to examine the potential impact of new aviation policies, can conduct a scenario-analysis based on this study. By developing different scenarios where a set of factors defined in this study are applied, it can be tested whether a new policy will potentially have the desired outcome or not. Not only the potential benefits have to be taken into account, but the (external) costs also have to be considered. If governments want to boost the air cargo market, there will probably be more employment, but also more externalities. Looking to these different aspects from a social welfare economic perspective is crucial.

Regarding future research, the options are broad. This paper will serve as the basic framework for quantitative research in the field of airport competitiveness in regard to cargo. Many different research methodologies could be used to quantify the different factors listed. It could be of interest to limit the number of factors to four or five major ones. In that way, assessing airport competitiveness would be more straight forward. Next, regression models could be developed to assess which factors are of major relevance for airport competitiveness and which only have limited impact. One could also define different types of airports based on the different factors defined. By giving a quite complete overview of factors determining the competitiveness of an airport regarding cargo activities, this study will be a good starting point for such further research. 


\section{REFERENCES}

- Adenigbo, J.A., 2016. Factors influencing cargo agents choice of operations in Abuja airport, Nigeria. J. Air Transp. Manag. 55, 113-119. https://doi.org/10.1016/j.jairtraman.2016.05.001

- Adler, N., Berechman, J., 2001. Measuring airport quality from the airlines' viewpoint: An application of data envelopment analysis. Transp. Policy 8, 171-181. https://doi.org/10.1016/S0967-070X(01)00011-7

- Adler, N., Liebert, V., 2014. Joint impact of competition, ownership form and economic regulation on airport performance and pricing. Transp. Res. Part A Policy Pract. 64, 92109. https://doi.org/10.1016/j.tra.2014.03.008

- Air Cargo World, 2018. New DHL Express hub in Brussels to quadruple regional capacity. https://aircargoworld.com/allposts/new-dhl-express-hub-in-brussels-to-quadrupleregional-capacity/ (accessed 17 April 2019).

- Air Cargo World, 2001. Converging on air freight 320-328.

- Air Transport World, 2002. Location, location, location 70-74.

- Airbus, 2015. Global Market Forecast. Toulouse, France.

- Alkaabi, K.A., Debbage, K.G., 2011. The geography of air freight: Connections to U.S. metropolitan economies. J. Transp. Geogr. 19, 1517-1529. https://doi.org/10.1016/j.jtrangeo.2011.04.004

- Amaruchkul, K., Lorchirachoonkul, V., 2011. Air-cargo capacity allocation for multiple freight forwarders. Transp. Res. Part E Logist. Transp. Rev. 47, 30-40. https://doi.org/10.1016/j.tre.2010.07.008

- ATAG, 2018. Aviation: Benefits without borders 2018. Geneva, Switzerland.

- Barrett, S.D., 2000. Airport competition in the deregulated European aviation market. J. Air Transp. Manag. 6, 13-27. https://doi.org/10.1016/S0969-6997(99)00018-6

- Basso, L.J., Zhang, A., 2010. Pricing vs. slot policies when airport profits matter. Transp. Res. Part B Methodol. 44, 381-391. https://doi.org/10.1016/j.trb.2009.09.005

- Ben-Akiva, M., Meersman, H., Van de Voorde, E., 2013. The Relationship between Economic Activity and Freight Transport, in: Ben-Akiva, M., Meersman, H., Van de Voorde, E. (Eds.), Freight Transport Modelling. Emerald Group Publishing Limited, Bingley, pp. 1743.

- Boeing, 2018. World Air Cargo Forecast 2018-2037. Seattle, USA.

- Boeing, 2016. World Air Cargo Forecast 2016-2017. Seattle, USA.

- Boonekamp, T., Burghouwt, G., 2017. Measuring connectivity in the air freight industry. J. Air Transp. Manag. 61, 81-94. https://doi.org/10.1016/j.jairtraman.2016.05.003

- Boquet, Y., 2009. Les hubs de fret aérien express (Express freight hubs). Bull. d'Association Géographes Fr. 86, 472-484. https://doi.org/10.3406/bafg.2009.2695 
- Bowen, J.T., 2012. A spatial analysis of FedEx and UPS: Hubs, spokes, and network structure. J. Transp. Geogr. 24, 419-431. https://doi.org/10.1016/j.jtrangeo.2012.04.017

- Bowen, J.T., 2004. The geography of freighter aircraft operations in the Pacific Basin. J. Transp. Geogr. 12, 1-11. https://doi.org/10.1016/S0966-6923(03)00024-3

- Budd, L., Ison, S., 2017. The role of dedicated freighter aircraft in the provision of global airfreight services. J. Air Transp. Manag. 61, 34-40. https://doi.org/10.1016/j.jairtraman.2016.06.003

- Burghouwt, G., Poort, J., Ritsema, H., 2014. Lessons learnt from the market for air freight ground handling at amsterdam airport schiphol. J. Air Transp. Manag. 41, 56-63. https://doi.org/10.1016/j.jairtraman.2014.06.016

- Chao, C.C., Yu, P.C., 2013. Quantitative evaluation model of air cargo competitiveness and comparative analysis of major Asia-Pacific airports. Transp. Policy 30, 318-326. https://doi.org/10.1016/j.tranpol.2013.10.001

- Chu, H.C., 2014. Exploring preference heterogeneity of air freight forwarders in the choices of carriers and routes. J. Air Transp. Manag. 37, 45-52. https://doi.org/10.1016/j.jairtraman.2014.02.002

- Chung, T.W., Han, J., 2013. Evaluating Competitiveness of Transshipment Cargo in Major Airports in Northeast Asia: Airport branding. Asian J. Shipp. Logist. 29, 377-394. https://doi.org/10.1016/j.ajsl.2013.12.005

- Copenhagen Economics, 2012. Airport competition in Europe. https://doi.org/10.1016/j.jairtraman.2017.03.005

- Cosmas, A., Martini, B., 2007. UPS and FedEx Air Hubs: Comparing Louisville and Memphis Cargo Hub Operations.

- de Wit, J., Merkert, R., Van de Voorde, E., 2017. Making or breaking - Key success factors in the air cargo market. J. Air Transp. Manag. 61, 1-5. https://doi.org/10.1016/j.jairtraman.2017.02.001

- Delve, K., 2001. Cargo growth. Airports Int. 34, 18-19.

- Dennis, N., 1994. Airline hub operations in Europe. J. Transp. Geogr. 2, 219-233. https://doi.org/10.1016/0966-6923(94)90047-7

- Dewulf, W., Meersman, H., Van de Voorde, E., 2014. From carpet sellers to cargo stars: Analyzing strategies of air cargo carriers. J. Air Transp. Stud. 5, 96-119.

- Elliott, D., Bonsignori, C., 2019. The influence of customs capabilities and express delivery on trade flows. J. Air Transp. Manag. 74, 54-71. https://doi.org/10.1016/j.jairtraman.2018.09.007

- Fichert, F., Klophaus, R., 2011. Incentive schemes on airport charges - Theoretical analysis and empirical evidence from German airports. Res. Transp. Bus. Manag. 1, 71-79. https://doi.org/10.1016/j.rtbm.2011.06.006

- Forsyth, P., 2006. Airport Competition: Regulatory Issues and Policy Implications, in: Lee, 
D. (Ed.), Competition Policy and Antitrust. Elsevier B.V., Amsterdam, pp. 347-368.

- Fuerst, F., Gross, S., 2018. The commercial performance of global airports. Transp. Policy 61, 123-131. https://doi.org/10.1016/j.tranpol.2017.08.005

- Gardiner, J., 2006. An international study of the airport choice factors for non- integrated cargo airlines. Loughborough University.

- Gardiner, J., Humphreys, I., Ison, S., 2005a. Freighter operators' choice of airport: A threestage process. Transp. Rev. 25, 85-102. https://doi.org/10.1080/0144164042000218409

- Gardiner, J., Ison, S., 2008. The geography of non-integrated cargo airlines: an international study. J. Transp. Geogr. 16, 55-62. https://doi.org/10.1016/j.jtrangeo.2007.02.005

- Gardiner, J., Ison, S., Humphreys, I., 2005b. Factors influencing cargo airlines' choice of airport: An international survey. J. Air Transp. Manag. 11, 393-399. https://doi.org/10.1016/j.jairtraman.2005.05.004

- Graham, A., 2014. Managing Airports - An international perspective, 4th ed. Routledge, Abingdon.

- Hall, R.W., 2002. Alternative Access and Locations for Air Cargo.

- Hall, R.W., 2001. Truck scheduling for ground to air connectivity. J. Air Transp. Manag. 7, 331-338. https://doi.org/10.1016/S0969-6997(01)00014-X

- Harris, C., 1954. The Market as a Factor in the Localization of Industry in the United States. Ann. Assoc. Am. Geogr. 44, 315-348.

- Heinitz, F., Hirschberger, M., Werstat, C., 2013. The Role of Road Transport in Scheduled Air Cargo Networks. Procedia - Soc. Behav. Sci. 104, 1198-1207. https://doi.org/10.1016/j.sbspro.2013.11.216

- Heinitz, F., Meincke, P., 2009. Systematizing Routing Options in a Global Air Cargo Network Model.

- Hsu, C.I., Li, H.C., Liao, P., Hansen, M.M., 2009. Responses of air cargo carriers to industrial changes. J. Air Transp. Manag. 15, 330-336. https://doi.org/10.1016/j.jairtraman.2009.06.002

- Hwang, C.C., Shiao, G.C., 2011. Analyzing air cargo flows of international routes: an empirical study of Taiwan Taoyuan International Airport. J. Transp. Geogr. 19, 738-744. https://doi.org/10.1016/j.jtrangeo.2010.09.001

- IATA, 2013. Airport Competition. Geneva, Switzerland.

- Kasarda, J.D., Green, J.D., 2005. Air cargo as an economic development engine: A note on opportunities and constraints. J. Air Transp. Manag. 11, 459-462. https://doi.org/10.1016/j.jairtraman.2005.06.002

- Kingsley-Jones, M., 2000. Express: Europe's express package carriers have undergone tremendous change in recent years as the cargo business has boomed. Flight Int. 158, $43-46$. 
- Kim, J.Y., Park, Y., 2012. Connectivity analysis of transshipments at a cargo hub airport. J. Air Transp. Manag. 18, 12-15. https://doi.org/10.1016/j.jairtraman.2011.05.001

- Kupfer, F., Goos, P., Kessels, R., Van de Voorde, E., Verhetsel, A., 2011a. The airport choices in the air cargo sector - A discrete choice analysis of freighter operations.

- Kupfer, F., Kessels, R., Goos, P., Van de Voorde, E., Verhetsel, A., 2016. The origindestination airport choice for all-cargo aircraft operations in Europe. Transp. Res. Part $\mathrm{E}$ Logist. Transp. Rev. 87, 53-74. https://doi.org/10.1016/j.tre.2015.11.013

- Kupfer, F., Meersman, H., Onghena, E., Van de Voorde, E., 2017. The underlying drivers and future development of air cargo. J. Air Transp. Manag. 61, 6-14. https://doi.org/10.1016/j.jairtraman.2016.07.002

- Kupfer, F., Meersman, H., Onghena, E., Van de Voorde, E., 2011b. Air freight and merchandise trade: towards a disaggregated analysis. J. Air Transp. Stud. 2, 28-48.

- Lafaye, A., 2007. Integrators' Air Network - A review of the Domestic Express European Market. Cranfield University.

- Lange, A., 2019. Does cargo matter? The impact of air cargo operations on departure ontime performance for combination carriers. Transp. Res. Part A 1219, 214-223. https://doi.org/10.1016/j.tra.2018.10.005

- Lee, H., Yang, H.M., 2003. Strategies for a global logistics and economic hub: Incheon International Airport. J. Postgrad. Inst. Med. 9, 113-121. https://doi.org/10.1016/S09696997(02)00065-0

- Li, Z., Bookbinder, J.H., Elhedhli, S., 2012. Optimal shipment decisions for an airfreight forwarder: Formulation and solution methods. Transp. Res. Part C Emerg. Technol. 21, 17-30. https://doi.org/10.1016/j.trc.2011.08.001

- Macário, R., 2008. Airports of the future: Essentials for a renewed business model. Eur. J. Transp. Infrastruct. Res. 8, 165-182. https://doi.org/10.4324/9780203845332

- Madas, M.A., Zografos, K.G., 2008. Airport capacity vs. demand: Mismatch or mismanagement? Transp. Res. Part A Policy Pract. 42, 203-226. https://doi.org/10.1016/j.tra.2007.08.002

- Magalhães, L., Reis, V., Macário, R., 2015. Can flexibility make the difference to an airport's productivity? An assessment using cluster analysis. J. Air Transp. Manag. 47, 90-101. https://doi.org/10.1016/j.jairtraman.2015.05.003

- Malighetti, P., Martini, G., Redondi, R., Scotti, D., 2016. The geography of integrators' air transport networks in Europe.

- Malighetti, P., Paleari, S., Redondi, R., 2009. Airport classification and functionality within the European network. Probl. Perspect. Manag. 7, 183-196. https://doi.org/10.1002/smj.2172

- Mayer, R., 2016. Airport classification based on cargo characteristics. J. Transp. Geogr. 54, 53-65. https://doi.org/10.1016/j.jtrangeo.2016.05.011 
- Merkert, R., Ploix, B., 2014. The impact of terminal re-organisation on belly-hold freight operation chains at airports. J. Air Transp. Manag. 36, 78-84. https://doi.org/10.1016/j.jairtraman.2014.01.003

- Murphy, P., Dalenberg, D., Daley, J., 1989. Improving international trade efficiency: Airport and air cargo concerns. Transp. J. 27-35.

- Neiberger, C., 2008. The effects of deregulation, changed customer requirements and new technology on the organisation and spatial patterns of the air freight sector in Europe. J. Transp. Geogr. 16, 247-256. https://doi.org/10.1016/j.jtrangeo.2007.09.003

- Nieuwsblad Transport, 2019. Kalitta Air wil sancties tegen VS tegen vrachtstop Schiphol.https://www.nieuwsbladtransport.nl/luchtvracht/2019/02/08/kalitta-air-wilsancties-vs-tegen-vrachtstop-schiphol/ (accessed 23 April 2019).

- Noviello, K., Cromley, R., Cromley, E., 1996. A comparison of the passenger and air cargo industries with respect to hub locations. Gt. Lakes Geogr. 3, 75-85.

- O'Kelly, M.E., 1986. The Location of Interacting Hub Facilities. Transp. Sci. 20, 92-106. https://doi.org/10.1287/trsc.20.2.92

- Ohashi, H., Kim, T.S., Oum, T.H., Yu, C., 2005. Choice of air cargo transshipment airport: An application to air cargo traffic to/from Northeast Asia. J. Air Transp. Manag. 11, 149159. https://doi.org/10.1016/j.jairtraman.2004.08.004

- Onghena, E., 2013. From Cost Structure to Strategy. University of Antwerp.

- Oosterlynck, S., Swyngedouw, E., 2010. Noise reduction: The postpolitical quandary of night flights at Brussels Airport. Environ. Plan. A 42, 1577-1594. https://doi.org/10.1068/a42269

- OSC, IWW, MKMETRIC, Vienna, T., Demis, 2009. WorldNet Final Report. Zoetermeer.

- Page, P., 2003. Selling cargo. Air Cargo World 93, 44-49.

- Rodrigue, J.-P., 2012. The Geography of Global Supply Chains: Evidence from Third-Party Logistics. J. Supply Chain Manag. 48, 15-23. https://doi.org/10.1111/j.1745493X.2012.03268.X

- Rodríguez-Déniz, H., Suau-Sanchez, P., Voltes-Dorta, A., 2013. Classifying airports according to their hub dimensions: An application to the US domestic network. J. Transp. Geogr. 33, 188-195. https://doi.org/10.1016/j.jtrangeo.2013.10.011

- Schramm, H.-J., 2012. Freight Forwarder's Intermediary Role in Multimodal Transport Chains - A Social Network Approach. Physica-Verlag. https://doi.org/10.1007/978-3-79082151-2

- Schwieterman, J.P., 1994. Express air cargo in the Pacific Rim : evaluation of prospective hub sites. Transp. Res. Rec. 1-7.

- Shaw, S.L., 1993. Hub structures of major US passenger airlines. J. Transp. Geogr. 1, 4758. https://doi.org/10.1016/0966-6923(93)90037-Z

- Starkie, D., 2002. Airport regulation and competition. J. Air Transp. Manag. 8, 63-72. 
https://doi.org/10.1016/S0969-6997(01)00015-1

- Struyf, E., 2016. Passengers, cargo and airport strategies.

- Struyf, E., Onghena, E., De Langhe, K., 2016. Where Rail Meets Air Cargo. The Potential of Rail As an Alternative To Road Transport in the Air Cargo Chain.

- Tretheway, M., Andriulaitis, R., 2010. Airport Competition for Freight, in: Forsyth, P., Gillen, D., Müller, J., Niemeier, H.-M. (Eds.), Airport Competition. Ashgate Publishing, Surrey, pp. 137-147.

- Wong, J.T., Chung, Y.S., Hsu, P.Y., 2016. Cargo market competition among Asia Pacific's major airports. J. Air Transp. Manag. 56, 91-98. https://doi.org/10.1016/j.jairtraman.2016.04.019

- Yuan, X.M., Low, J.M.W., Ching Tang, L., 2010. Roles of the airport and logistics services on the economic outcomes of an air cargo supply chain. Int. J. Prod. Econ. 127, 215-225. https://doi.org/10.1016/j.ijpe.2009.08.005

- Yuen, A., Zhang, A., Hui, Y. Van, Leung, L.C., Fung, M., 2017. Is developing air cargo airports in the hinterland the way of the future? J. Air Transp. Manag. 61, 15-25. https://doi.org/10.1016/j.jairtraman.2016.09.009

- Zhang, A., 2003. Analysis of an international air-cargo hub: The case of Hong Kong. J. Air Transp. Manag. 9, 123-138. https://doi.org/10.1016/S0969-6997(02)00066-2

- Zhang, A., Zhang, Y., 2002. Issues on liberalization of air cargo services in international aviation. J. Air Transp. Manag. 8, 275-287. https://doi.org/10.1016/S09696997(02)00008-X

\section{AUTHORS' BIOS}

Thomas Van Asch (corresponding author) is a PhD fellow at the Faculty of Economics of the University of Antwerp. He finished his Master of Applied Economics at the University of Antwerp, and his Master of Air Transport Management at C-MAT. His main areas of research are Airport Strategy and E-commerce Strategy Development.

E-mail: Thomas.VanAsch@uantwerp.be

Dr Wouter Dewulf graduated as a Doctor in Applied Economics at the University of Antwerp. $\mathrm{He}$ is a professor at the University of Antwerp and C-MAT (Belgium). His main areas of research are in the fields of air cargo, airline strategy and airport strategy. He is a visiting professor at University of Hasselt (Belgium) and University of Chongqing (China). His PhD dealt with the strategy of air cargo carriers. E-mail: Wouter.Dewulf@uantwerp.be 
Dr Franziska Kupfer obtained her $\mathrm{PhD}$ on the airport choice for scheduled freighter operations in Europe at the University of Antwerp in 2012. Until 2019 she worked as an Assistant Professor and Post-doc researcher at the Department of Transport and Regional Economics/C-MAT, focusing her research on air transport and airport economics as well as general transport economics. Since 2019 she stays connected with the department and the University of Antwerp as a volunteer. E-mail: Franziska.Kupfer@uantwerp.be

Professor Hilde Meersman is a Full Professor at the University of Antwerp. Her research activities are on the intersection of transportation economics, macroeconomics and economic modelling. She has been involved in many research projects on topics such as modelling and forecasting commodity transportation, and the empirical analysis of port and airport competition. E-mail: Hilde.Meersman@uantwerp.be

Dr Evy Ongena holds a PhD from the University of Antwerp in the field of air cargo economics in which she developed a translog cost model for integrators. Evy worked as a post-doc member of the Department of Transport and Regional Economics of the University of Antwerp between 2013 and 2019. Her main area of research is air transport economics.

E-mail: Evy.Onghena@uantwerp.be

Professor Eddy Van de Voorde is a Full Professor at the Department of Transport and Regional Economics of the University of Antwerp. He focuses on Air Transport Economics, Maritime Economics and Port Economics. He is a Visiting Professor at several Belgian and foreign universities. E-mail: Eddy.VandeVoorde@uantwerp.be 